\title{
Influence of Chelidonium majus Water Extract onto Cancer Cells and Platelets
}

\author{
Deulenko VN¹, Marunych RY²*, Chernyshenko VO², Rebriev AV ${ }^{2}$, Lugovskoy EV ${ }^{2}$, Garmanchuk LV³ and Pavliuk OV \\ ${ }^{1}$ Kyiv International University, 49 Lvivska St, Kyiv, 03179, Ukraine \\ ${ }^{2}$ Palladin Institute of Biochemistry of the National Academy of Sciences of Ukraine (NASU), 9 Leontovich St, 01030 Kyiv, Ukraine \\ ${ }^{3}$ Taras Shevchenko National University of Kyiv, 64 Volodymyrska St, 01033 Kyiv, Ukraine
}

\begin{abstract}
The plant C. majus (Celandine) is a known source of biologically active compounds that are used in traditional medicine for preventing or curing cancer diseases. The growing interest in this plant is due to discovery of a number of plant-derived cytostatics and anti-blastic drugs. The goal of our study was to discover the influence of a water extract from these plants on cancer cells and to characterize the obtained extract using different analytical methods.

Water extract of leaves of $C$. majus were obtained and lyophilized on TelStar LyoQuest (Spain). Composition of the extract was characterized using HPLC Agilent 1100, SDS-PAGE electrophoresis and MLADI-TOF Mass-spectrometry. ADP-induced platelet aggregation in the presence of obtained mixture was studied by aggregometry using Solar2110 (Belorussia). Effects of the extracts on proliferation of cancer cells was estimated using MTT-test.

Investigation of $C$. majus extract demonstrated presence of chelerythrine and precursors of berberine alkaloids in it.

Addition of $C$. majus extract to platelet rich plasma induced moderate platelet activation (up to $10 \%$ ). This aggregation was reversible. Further ADP-induced activation of platelets pre-incubated with the extract was diminished on $30 \%$. The extract of $C$. majus leaves also was shown to possess anti-proliferative agent that was demonstrated on MCF-7 cancer cells. The surviving of MCF-7 coulter cells was decreased to $40 \%$ in the presence of extract.

In conclusion, direct action of $C$. majus extract components on platelet aggregation and cancer cell proliferation was observed. Further fractionation for the determination of functionally active components of $C$. majus extract is promising for biotechnology and medicine.
\end{abstract}

Keywords: C. majus; Extract; Cancer cells; Platelets

\section{Introduction}

Wild plant C. majus (Celandine) is a known source of biologically active compounds that are used in traditional medicine for preventing or curing of cancer diseases. The compounds of natural plant origin are being studied as modern agents for antitumor therapy. The growing interest for these compounds is explained by the discovery and detailed study of a number of plant-derived cytostatics and the successful application of such anti-blastic drugs as colchamine, vinblastine, vincristine, podophilin, and others [1-3].

Alkaloids should be named among the compounds of plant origin. This is a group of biologically active heterocyclic nitrogen-containing substances. Extract of celandine (C. majus L.) contains about 35 alkaloids $[1,4]$ with protopinic, protoberberin and benzophenanthridine structure. Among alkaloids contained in the extracts of C. majus are chelidonin, sanguinarine, berberin, narcissine and coptisin.

The biological activity of many compounds of $C$. majus leaves were demonstrated in the recent years. In particular, it has been established that the chelidonin interacts with tubulin causing the termination of the mitosis phase [5] chelidonine has several pharmacological effects $[6,7]$. Heliterrin, sanguinarine, berberine and coptisin affect the processes of respiration in mitochondria, berberine affects platelet activation [8], berberine is a reversible inhibitor of acetylcholinesterase [9] and pure berberin is the trombin inhibitor and inhibitor of platelets aggregation [10]. It was steadied in case of cardiovascular and thrombotic deceases [11], but FDA declined it in clinical trials, because of risk cytotoxicity [12]. Also, it demonstrates effect onto arachidonic acid metabolism [13] and the thromboxane B2 (TXB2) and 6-ketoprostaglandin F1 alpha (6-keto-PGF1 alpha) [14], caused to platelet aggregation and makes effect onto endothelial cells. It was found, that berberine is NF-k-B activator, inhibitor of $\mathrm{N}$-acetyltransferase, cyclooxygenase- 2 and topoisomerase and and is an inducer of apoptosis $[15,16]$. Chelerythrine is a protein kinase C inhibitor [17], protopine inhibits voltage- and receptor-operated calcium channels [18], and sanguinarine is a potent inhibitor of nuclear factor (NF-kB) involved in the activation of tumor necrosis factor gene expression [19]. Due to the presence of iminogroups, sanguinarine and helitrin can inhibit the activity of enzymes that have nucleophilic groups in the active center [20]. Some alkaloids of C. majus act as inhibitors of protein kinase, blocking the activity of the transcription factor NF-kB, which is a component of signaling pathways involved in induction of cell proliferation or apoptosis [21]. Authors pay attention to the ability of individual alkaloids of celandine to interact with DNA by penetrating their planar molecular structures in DNA strands [2].

Development of alkaloid-based drugs with antitumor activity is an important issue of biotechnology [22-24]. The mechanisms of alkaloids suppression of the growth of tumors is not well understood,

*Corresponding author: Marunych RY, Palladin Institute of Biochemistry of the National Academy of Sciences of Ukraine (NASU), 9 Leontovich St, 01030 Kyiv, Ukraine, Tel: +38(050)014-93-50; E-mail: rostmarbiotech@gmail.com

Received: December 10, 2018; Accepted: December 17, 2018; Published December 24, 2018

Citation: Deulenko VN, Marunych RY, Chernyshenko VO, Rebriev AV, Lugovskoy EV, et al. (2018) Influence of Chelidonium majus Water Extract onto Cancer Cells and Platelets. Biochem Anal Biochem 7: 370. doi: 10.4172/2161-1009.1000370

Copyright: (c) 2018 Deulenko VN, et al. This is an open-access article distributed under the terms of the Creative Commons Attribution License, which permits unrestricted use, distribution, and reproduction in any medium, provided the original author and source are credited. 
in particular, the mechanisms of action of the celandine alkaloids, which are involved in induction of death of tumor cells, remain poorly understood and needs to be clarified. It is unclear, which of the alkaloids of $C$. majus is the most effective pro-apoptotic agent and whether there are other types of cell death that can be induced under the influence of alkaloids of C. majus.

That is why the present study deals with effects of water lyophilised extracts of C. majus leaves and flowers on isolated human platelets and adenocarcinoma cells of mammal gland, MCF-7.

\section{Materials and Methods}

\section{Chemicals}

In this study we used: acetonitrile, ammonium sulfate HPLC, acrylamide and bisacrylamide, Glycine and TRIS, SDS, HCl HPLCgrade, cultural medium DMEM, fetal bovine serum, heparin sodium salt, Ficoll Histopaque, Pencillin-streptomycin solution, Fetal bovine serum, (Sigma Aldrich, USA), MTT (Abcam, USA) and trypan blue dye (Thermo Fisher Scientific, USA), W.B.C. diluting fluid (Qualigen, India). Tris and sodium chloride HPLC grade (Fluka, Monte Carlo), ADP chemistry pure (Merck, Germany).

\section{Chelidonium majus extract}

Water extracts of leaves of medicinal plant was obtained from dried plants (leaves and flowers, obtained in the period of flowering, drying at $+20^{\circ} \mathrm{C}$ in the shadow). For preparation extract with volume $200 \mathrm{ml}$ $4 \mathrm{~g}$ of milled and dried plant were taken. It was washed by bubbling up water and infused 30 minutes under closed lid. Then it was filtered through paper filter and concentrated using lyophilization on TelStar LyoQuest (Spain). Firstly, extract was frozen in the flask using liquid nitrogen, than flask was connected to TelStar LyoQuest with heating and vacuum during 24 hours. Lyophilized brown colored powder was removed to $1.5 \mathrm{ml}$ plastic flasks. For characterization with HPLC powder was dissolved in deionized distilled water in concentration of $3 \mathrm{mg}$ per $\mathrm{ml}$.

\section{Platelet rich plasma}

Platelet rich plasma samples were obtained from blood of healthy donors. Volunteers signed informed consent prior to blood sampling according to the Helsinki declaration. Platelet rich plasma (PRP) was prepared from human citrated blood by centrifugation at $1000 \mathrm{rpm}$ during $20 \mathrm{~min}$.

\section{MCF-7 cell line}

MCF-7 breast cancer cell lines (Sigma collection obtained) $[25,26]$. Cells were cultured in a medium with $4500 \mathrm{mg} / \mathrm{l}$ glucose (DMEM, Dubecco's Modified Eagle Medium, Sigma, USA) and supplemented with $10 \%$ fetal bovine serum (FBS, Sigma, USA) for $3 \mathrm{~h}$ at $37^{\circ} \mathrm{C}, 5 \%$ $\mathrm{CO}_{2}$ in $\mathrm{CO}_{2}$ incubator and grown to confluence at $37^{\circ} \mathrm{C}$ in $5 \% \mathrm{CO} 2$ in a humidified atmosphere in a $\mathrm{CO}_{2}$ incubator (MMM, Medcenter Entrichungen $\mathrm{GmbH}$ MM-Group). The cells were trypsinized [500 $\mu \mathrm{l}$ of $0.025 \%$ Trypsin in PBS/0.5 mM EDTA solution (Sigma, USA)] for 2 min and passaged in 96-well Assay Plate, Corning Incorporation, COSTAR) in complete aseptic conditions.

\section{Lymphocyte preparation from human blood}

Lymphocytes were obtained from human venous blood using Ficoll gradient method, as described $[27,28]$. Number of living cells were controlled with trypan blue strain under microscope. Cells were cultured in DMEM culture as described [29,30]. Cultivation of human lymphocytes was carried out at the same condition as MCF-7 and by the same protocol.

\section{HPLC-chromatography}

Chromatographic system Agilent 1100 was used for analysis of extract with column Dupont Instrument $(250 \mathrm{~mm}$ long and $4.7 \mathrm{~mm}$ over) with Zorbax Silicogel $(20 \mathrm{mkm})$ with phenyl inoculation in pressure of 140 bar and flow $1.5 \mathrm{ml}$ per minute. There was used buffer gradient decreasing $0.15 \mathrm{M}$ TRIS $\mathrm{HCl} \mathrm{pH} 6.5,0.13 \mathrm{M} \mathrm{NaCl}$ and incising $50 \%$ Acetonitrill contained buffer with $0.1 \%$ trifluoracetic acid in 70 minutes long.

\section{SDS-PAGE}

Dried C. majus extract was dissolved in sample buffer containing $4 \%$ SDS, $0.5 \% \beta$-mercaptoethanol, $5 \%$ glycerol and blue dye bromophenol. Then it was analyzed by SDS-PAGE 15\% gel according to Laemmli [31].

\section{Xanthoproteic Test}

Xanthoproteic Test was used for characterization of protein content of the extract. One volume of extract was mixed with an equal volume of nitric. Mixture was heated and then cooled, then it was slowly mixed with $40 \%$ sodium hydroxide until the mixture becomes alkaline and a color change is noted. Yellow or orange color indicates the presence of an aromatic amino acid.

\section{Steady-state absorption spectra}

The differential absorbance spectra were recorded in the 200-700 $\mathrm{nm}$ range using spectrophotometer Optizen-POP (Optizen, Korea).

\section{MALDI-TOF analysis}

MALDI-TOF analysis of C. majus extract was performed using a Voyager-DE (Applied Biosystems, USA). H+-matrix ionization of polypeptides with sinapine acid (Sigma-Aldrich) was used. Results were analyzed by Data Explorer 4.0.0.0 (Applied Biosystems) [32].

\section{Cell line experiments}

MCF-7 cells were incubated in DMEM medium supplemented with $10 \% \mathrm{FBS}, 40 \mathrm{mg} / \mathrm{ml}$ gentamicin at standard conditions (at $37^{\circ} \mathrm{C}$ in $5 \% \mathrm{CO}_{2}$ ) during two days. C. majus extract was dissolved in the cell's medium DMEM, used for cells treatment. Dissolved extract was dose titrated by binary dissolution from $3 \mathrm{mg} / \mathrm{ml}$ to $0.012 \mathrm{mg} / \mathrm{ml}$ in final concentration in the cell's medium DMEM with serum.

Cell viability was measured by MTT-colorymetric test. The cell proliferation was expressed as percentage of the viable cell number of the control (non-treated cells). MCF-7 cell surviving was analyzed using trypan blue treatment [33]. It was added with $0.4 \%$ $\mathrm{w} / \mathrm{v}$ freshly filtered trypan blue dissolved in an identical medium to cells. Thereafter, MCF-7 cells are counted on a microscope in Haryev chamber, and the percentage viability is calculated by dividing the number of viable (unstained) cells by the number of all counted cells (stained and unstained).

\section{Platelet aggregation study}

$\mathrm{CaCl}_{2}(0.1 \mathrm{mM})$ and $10-20 \mu \mathrm{L}$ of $C$. majus extract were added to 200 $\mu \mathrm{L}$ of PRP and incubated in the aggregometer tube at constant spinning during $5 \mathrm{~min}$. The extent of aggregation was monitored by SOLAR aggregometer (Belorussia). Then aggregation was started by addition of $12.5 \mu \mathrm{M}$ ADP and also monitored as described above. 


\section{Results}

\section{C. majus extract characterization}

Dried extract of C. majus was characterized by HPLC, MALDITOF analysis, SDS-PAGE and spectra adsorption study. All these method allowed as directly or indirectly estimate the content of water extract that we aimed to study.

Absorption study demonstrated maximal absorption in UV diapason, with main peak of $210 \mathrm{~nm}$ Figure 1. Thus we could suggest that main components of studied extracts are alkaloids that have maximal adsorption meanings in this region of spectra [34].

SDS-PAGE and Xanthoproteic Test showed no proteins in the mixture even after concentrating by ten times so we can conclude that any possible biological effects of extracts can be caused by protein content.

HPLC fractionation of extract of C. majus demonstrated the presence of several major fractions. In particular, we detected small high molecular weight fraction and two or three low-molecular weight fractions that we assumed as alkaloids (Figure 2).

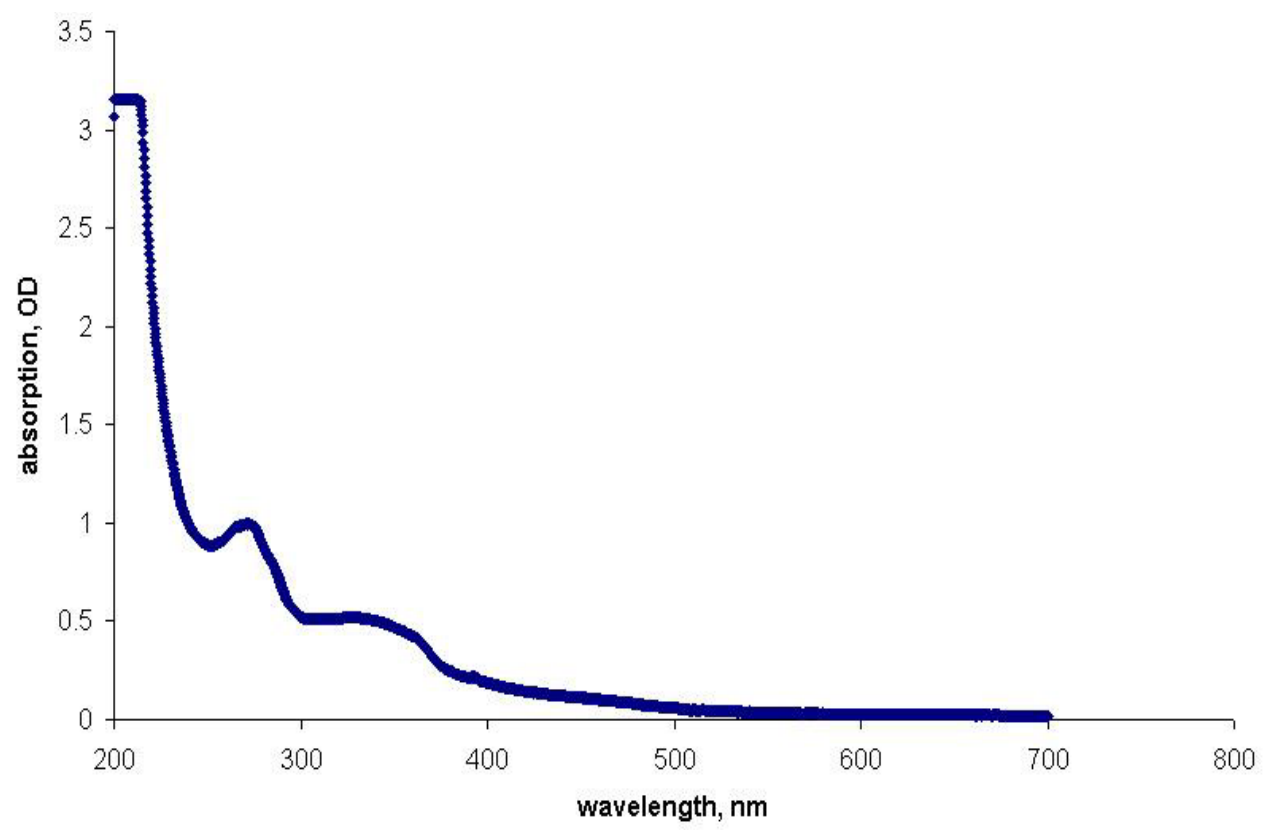

Figure 1: Spectra of adsorption of Chelidonium majus extract with maximal absorption at $210 \mathrm{~nm}$.

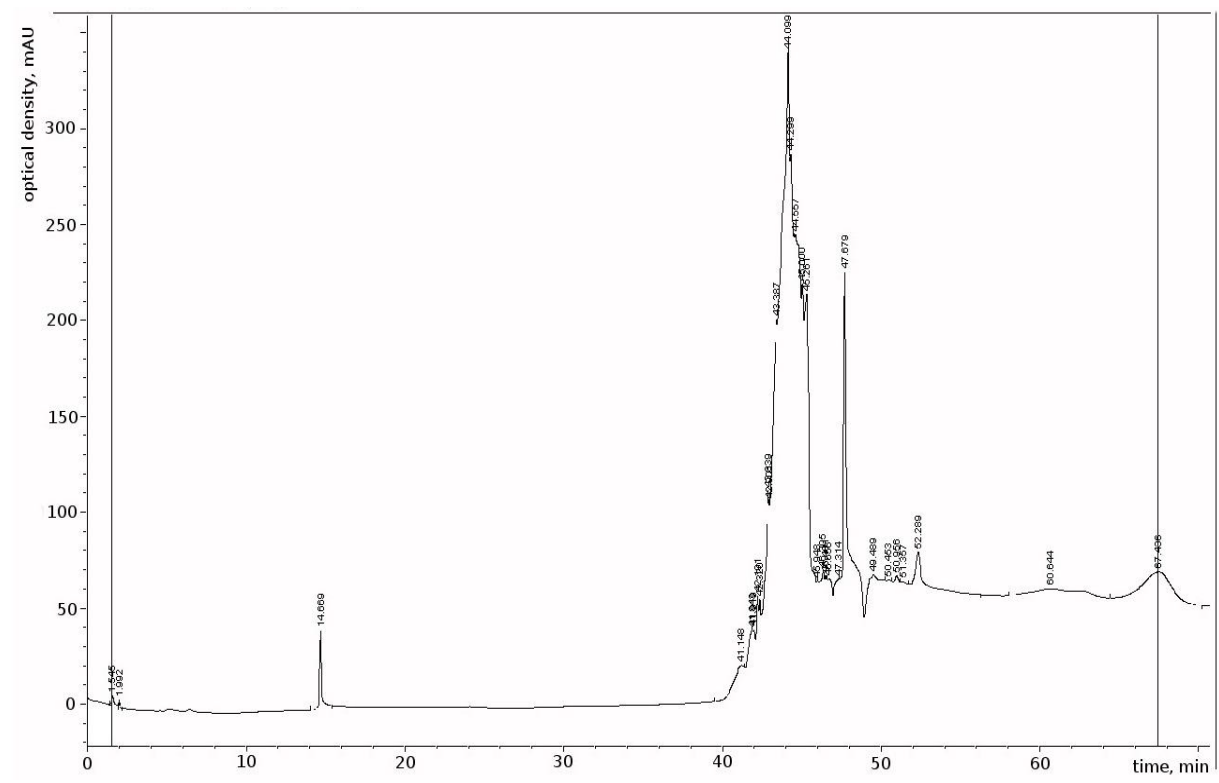

Figure 2: HPLC chromatogram of Chelidonium majus extract performed on chromatographic system Agilent 1100 , column Dupont Instrument (250 mm long and $4.7 \mathrm{~mm}$ over) with Zorbax Silicogel $(20 \mu \mathrm{m})$ with phenyl inoculation in pressure of 140 bar and flow $1.5 \mathrm{ml}$ per minute. There was used buffer gradient decreasing $0.15 \mathrm{M}$ TRIS HCl pH 6.5, $0.13 \mathrm{M} \mathrm{NaCl}$ and incising $50 \%$ Acetonitrill contained buffer with $0.1 \%$ trifluoracetic acid in 70 minutes long. 
To prove this suggestion we performed MALDI-TOF analysis that allowed us to identify two major components of extract with molecular weight $338 \mathrm{Da}$ and $320 \mathrm{Da}$ (Figure 3). First peak most probably belongs to alcaloids from Berberine family, that has molecular weight 338 $\mathrm{Da}$. Possible, it were jatrorrhizine, N-methylstylopine, tetracosane, $\mathrm{N}$-methyltetrahydrocoptisine, 13-hydroxylberberraline, columbamine, dehydrocorytenchine. All this alcaloids are precursoric methabolites of berberine, coptisine and jatrorrhizine. The second represents chelerythrine that is major alkaloid component of species of the tribe Chelidonieae of the Papaveraceae family and has molecular weight of $320 \mathrm{Da}$.

Possible, it were 9,10-didemethylchelerythrine or 7,8didemethylchelerythrine. Both alkaloids were previously found in plants from the family of Papaveraceae and could be found in C. majus extract $[34,35]$.

Thus, we obtained the extract of C. majus that was characterized and lyophilized for further studies. It contained mostly alkaloids precursors of berberine and chelerythrine that were identified using MALDI-TOF mass-spectrometry [36-39].

\section{Action of C. majus extract on platelet aggregation}

In further studies we examined the effect of C. majus extract on platelet aggregation. We aimed to investigate its effects on resting or ADP-activated platelets by aggregometry.

It was demonstrated that $C$. majus extract taken in final concentration $0.1 \mathrm{mg} / \mathrm{ml}$ and $0.06 \mathrm{mg} / \mathrm{ml}$ induced platelet activation that leads to moderate aggregation (rate of aggregation 10\%) (Figure 4).

When platelets that were pre-incubated with C. majus extract during $1 \mathrm{~min}$ were activated by ADP the decreasing of the rate of aggregation was observed (Figure 5). The rate of aggregation of platelets pre-incubated with $0.1 \mathrm{mg} / \mathrm{ml}$ or $0.06 \mathrm{mg} / \mathrm{ml}$ of extract decreased on $30 \%$ and $40 \%$ respectively (Figure 5 ). It can be explained by initial activation of platelets by the extract that take some part of cells out of the aggregation process induced by ADP.
Thus, we suggested that this effect must be caused by chelerythrine or berberine precursors and berberine-like alkaloids content of the extract. This is an opposite effect, that shown for pure berberine [1014]. We thought, that we got precursors of main alkaloids not because of degradation them during extraction, but because of harvesting young flowering plants, where main alkaloids has not been synthesized yet. In accordance with farmacognosia recommendation, often were used root of this plant, harvesting in autumn. It has different alkaloids composition. So, anticancer and platelets activation of extract, obtained from flowering plant was study firstly. And in comparison with another pure anticancer alkaloids, derived from different plants, our extract demonstrated lower activity, because of presents ballast compounds with a high molecular weight, and lower concentration of active compounds [40].

\section{Antiproliuferative action of Chelidonium majus extract}

Also C. majus extract taken in concentration of $3 \mathrm{mg} / \mathrm{ml}$ and 1.5 $\mathrm{mg} / \mathrm{ml}$ demonstrated cytopathogenic effect on MCF-7 cells (Figures 6 and 7). Addition of extract decreased the surviving of MCF-7 coulter cells determined using MTT-test to $40 \%$ and showed total mortality in test with trypan blue treatment.

The dose-dependent cytopatogenic effect of the studied extract is clearly demonstrated in Figure 6. Viability of cells determined with MTT-test was decreased significantly in the presence of C. majus extract. In particular it decreased in $50 \%$ in the presence of $0.375 \mathrm{mg} /$ $\mathrm{ml}$ of extract.

In comparison with positive control on human lymphocytes showed present of cytotoxic effect with concentrations of extract upper $2 \mathrm{mg} / \mathrm{ml}$, as it described in Figure 7. An optimal dose that inhibits MCF-7 cells and has low toxicity was between 1 and $2 \mathrm{mg} / \mathrm{ml}$, as it was shown for dose $1.5 \mathrm{mg} / \mathrm{ml}$.

Also, it was shown an influence of Chelidonium majus extract onto cell membrane permeability. Analysis of the number of dead cells using trypan blue demonstrated that the dose of $0.375 \mathrm{mg} / \mathrm{ml}$ possessed

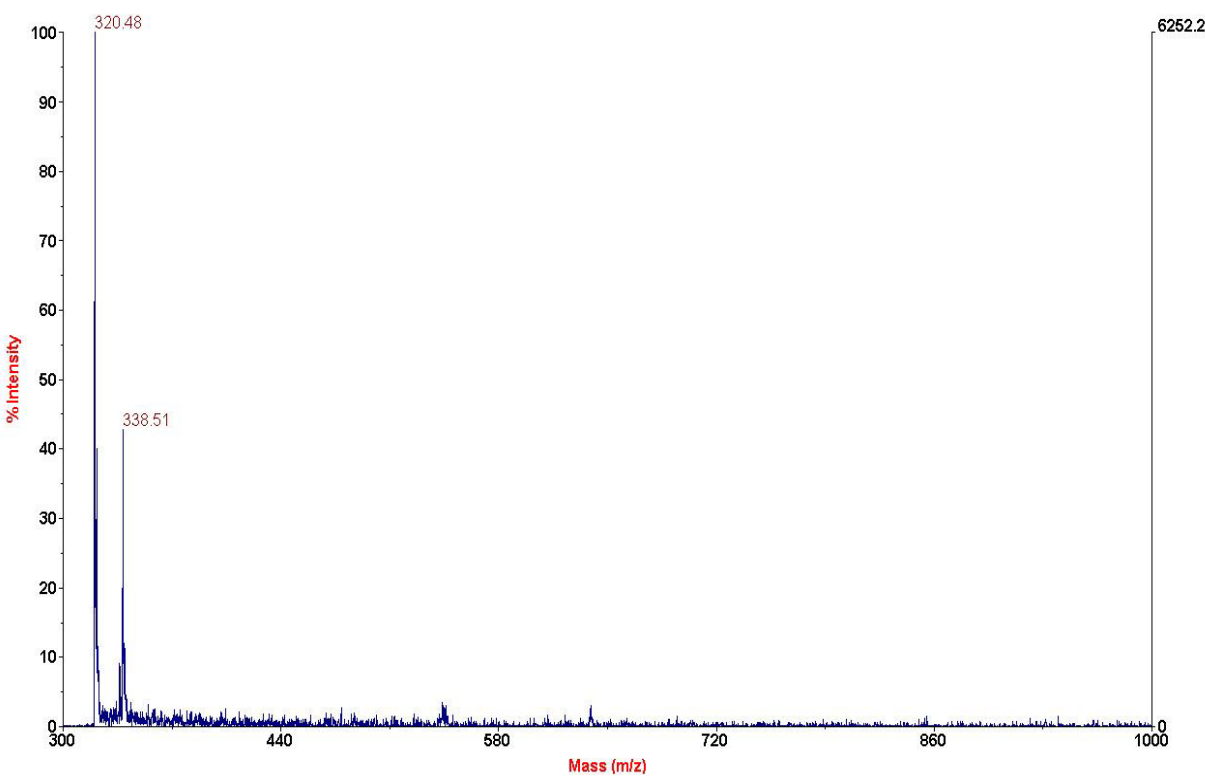

Figure 3: MALDI-TOF Spectra of $C$. majus extract representing two peaks that belong to alcoloids chelidonine and berberine. 


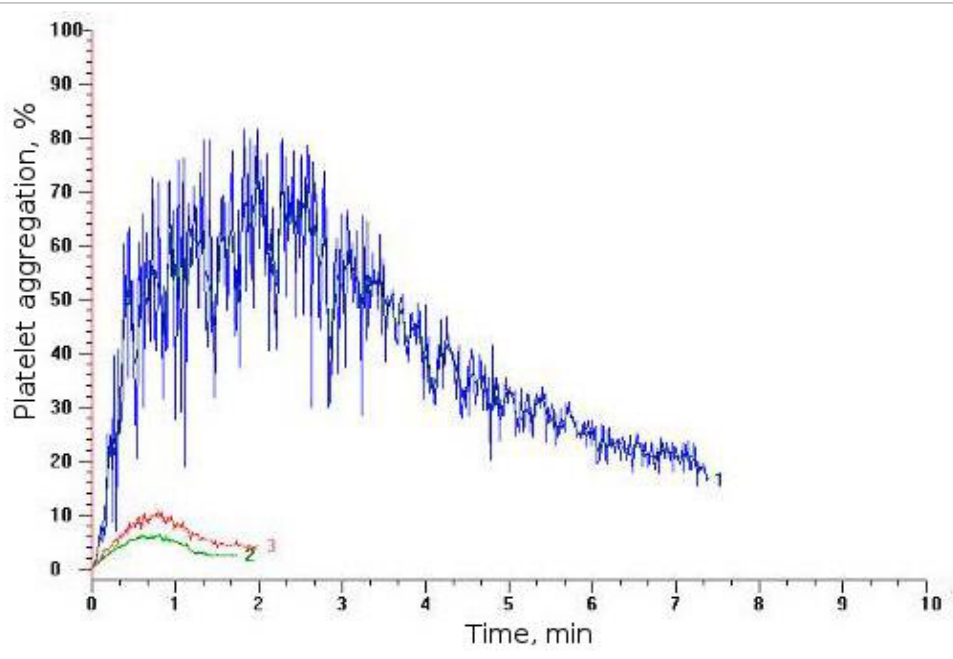

Figure 4: Aggregation of platelets in PRP induced by Chelidonium majus extract ( $3 \mathrm{mkg} / \mathrm{ml})$ without ADP (2-10 mkl, 3-20 mkl) and control (ADP-induced aggregation of platelets-1).

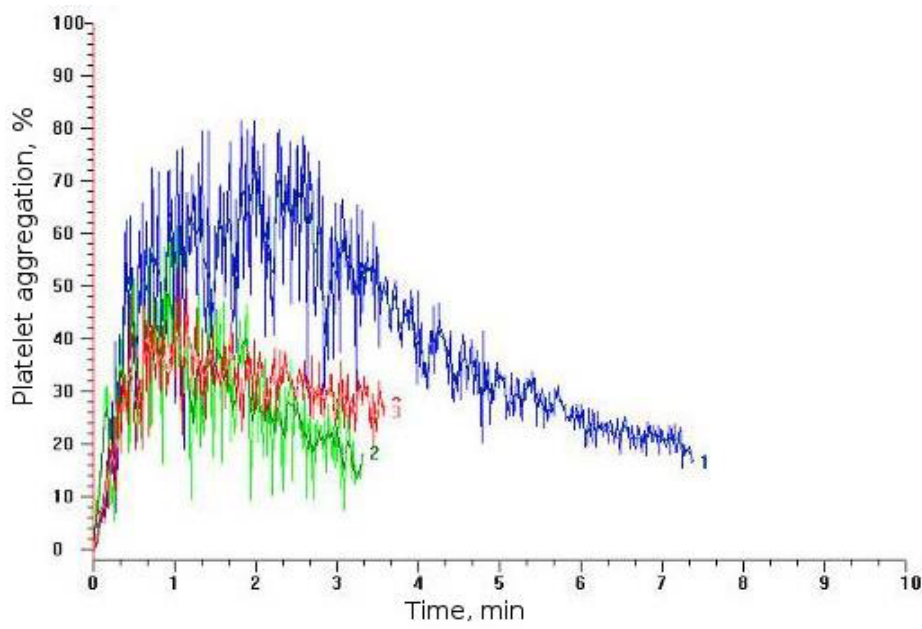

Figure 5: ADP-induced aggregation of platelets in PRP after $5 \mathrm{~min}$ incubation with Chelidonium majus extract $(2-0.1 \mathrm{mg} / \mathrm{ml} ; 3-0.06 \mathrm{mg} / \mathrm{ml})$ and control (incubated with equivalent volume of buffer-1).

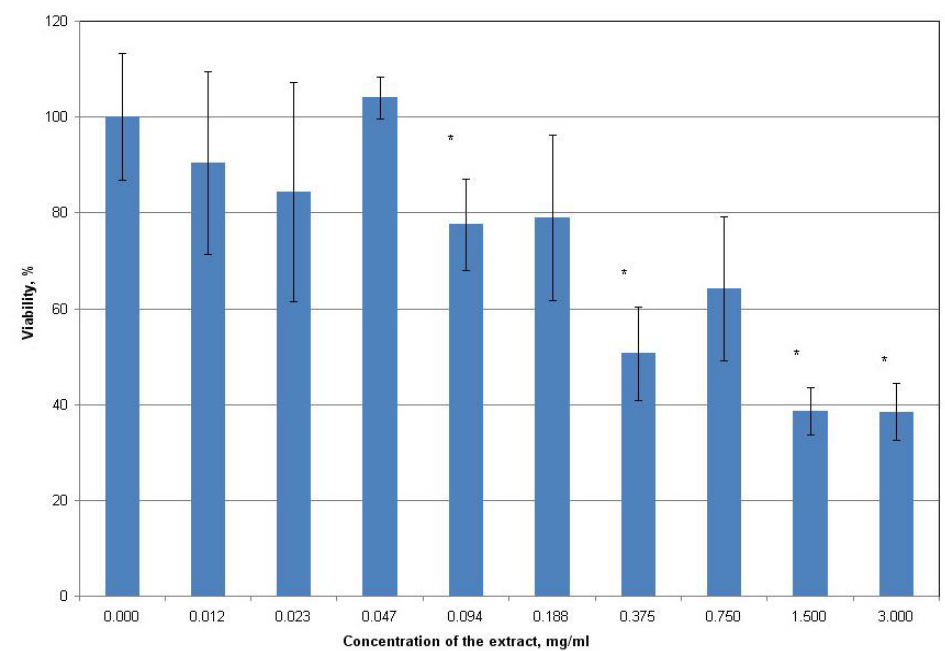

Figure 6: MTT test of surviving MCF-7 cells under treatment with Chelidonium majus extract. "results were significant for $p<0.05$. 
Citation: Deulenko VN, Marunych RY, Chernyshenko VO, Rebriev AV, Lugovskoy EV, et al. (2018) Influence of Chelidonium majus Water Extract onto Cancer Cells and Platelets. Biochem Anal Biochem 7: 370. doi: 10.4172/2161-1009.1000370

Page 6 of 8

effective antiproliferative action and the maximal dose decreased the level of living cells almost to the baseline (Figure 8).

Data of optical microscopy presented in Figure 9 demonstrates the cell layers in the presence of $C$. majus extract in comparison to control plates. Decreasing of cell number was detected and the staining with trypan blue indicated that most of cells in experimental sample were dead (Figure 9).

\section{Conclusion}

Spectra adsorption, HPLC and mass spectra demonstrated that dried extract of C. majus consist of alkaloids with fluorescence at 220-480 $\mathrm{nm}$ and maximum adsorption at $210 \mathrm{~nm}$. MALDI-TOF analysis identified in the extract alkaloids from berberine family and chelerythrine. In our studies the moderate platelet-activating effect of the studied extract we showed too. We assumed that this effect was caused mainly by berberin precursors.

Chelerythrine that was identified in the extract was shown to possess anti-proliferative activity towards MCF-7 cancer cells. It was shown that under concentration of extract in medium $1.5-3 \mathrm{mg} / \mathrm{ml}$ all cells died and MTT test showed residual activity in the rank of $40 \%$.

As to control lymphocytes a cytotoxic effect of the extract was observed only at concentration $3 \mathrm{mg} / \mathrm{ml}$ that was twice higher compared to the optimal inhibition dose shown for MCF-7 cells $(1.5 \mathrm{mg} / \mathrm{ml})$.

Further studies of the biological effects of plant extracts containing precursors of berberine and chelerythrine can be promising for the development of antithrombotic and anticancer drugs.

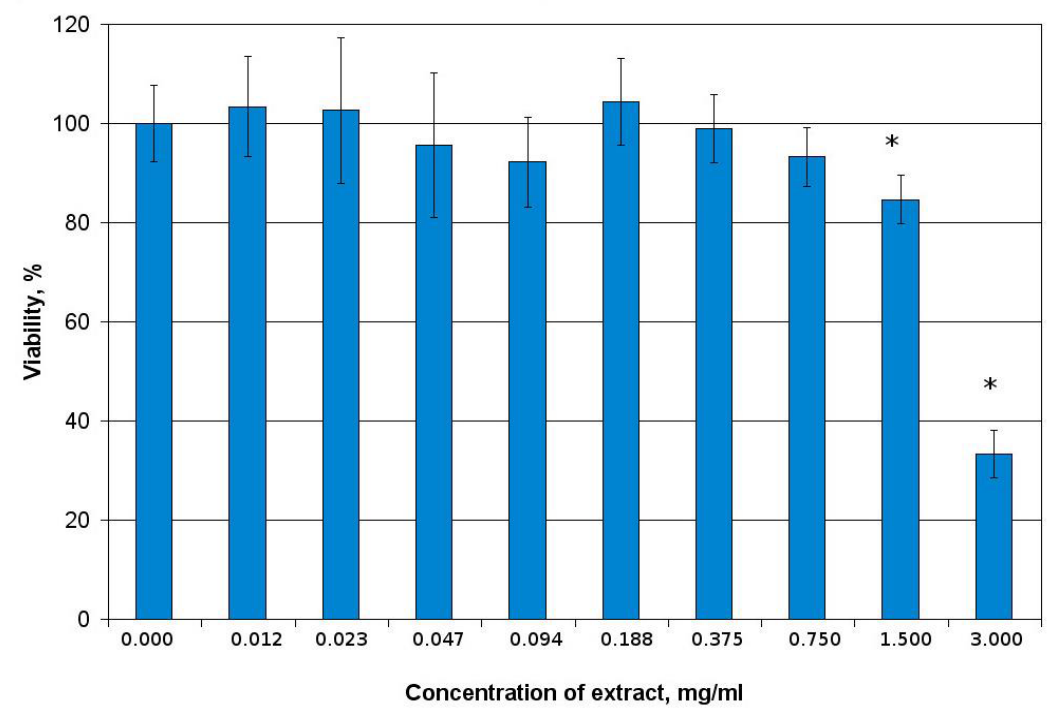

Figure 7: MTT test of surviving lymphocytes under treatment with Chelidonium majus extract. All results were significant for $p<0.05$.

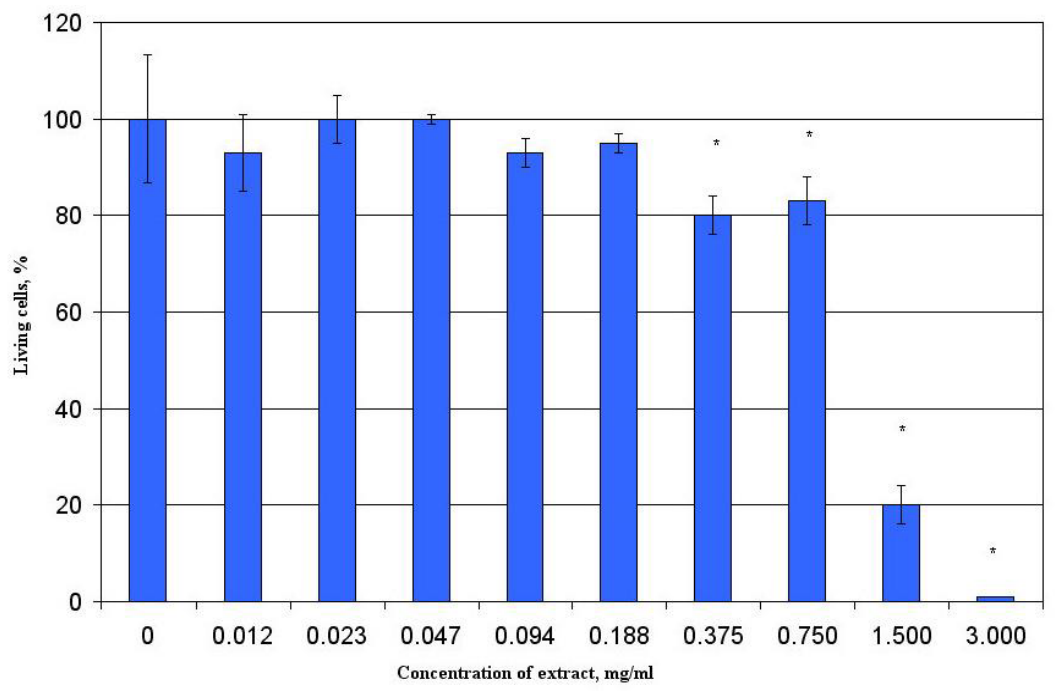

Figure 8: Total mortality in test with trypan blue treatment of MCF-7 cells under treatment with Chelidonium majus extract. "results were significant for p<0.05. 
Citation: Deulenko VN, Marunych RY, Chernyshenko VO, Rebriev AV, Lugovskoy EV, et al. (2018) Influence of Chelidonium majus Water Extract onto Cancer Cells and Platelets. Biochem Anal Biochem 7: 370. doi: 10.4172/2161-1009.1000370
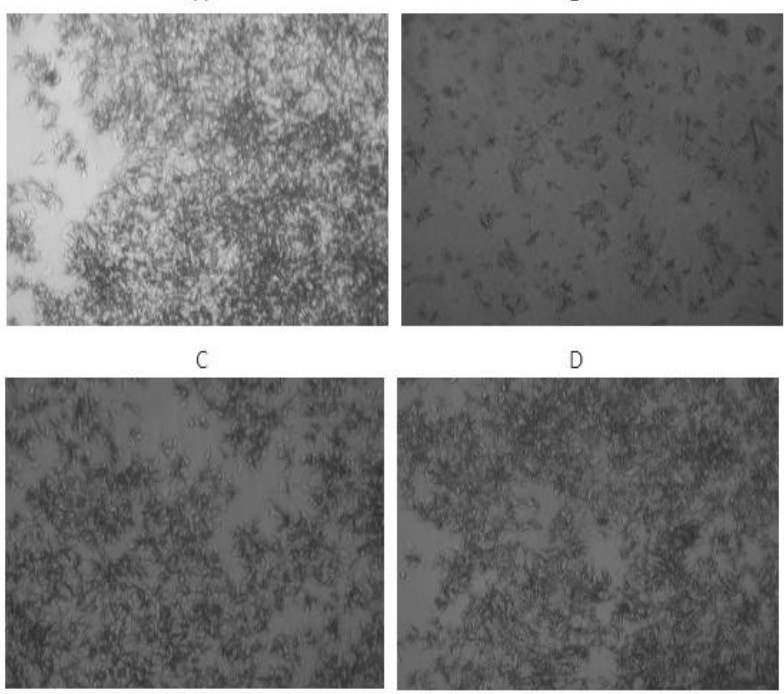

Figure 9: Influence of treatment MCF-7 with Chelidonium majus extract in concentrations $3 \mathrm{mg} / \mathrm{ml}(\mathrm{B}), 0.04 \mathrm{mg} / \mathrm{ml}(\mathrm{C})$ and $0.005 \mathrm{mg} / \mathrm{ml}(\mathrm{D})$ and control without treatment $(\mathrm{A})$. Stained with MTT test solution, recovered to the formazan.

\section{Acknowledgement}

This work was carried out in the framework of the basic theme of the Palladin Institute of Biochemistry of NAS of Ukraine "Study of regulation mechanisms of blood coagulation and fibrinolysis interplay with vascular and platelet hemostasis".

\section{References}

1. Potopalskij Al (1992) Preparaty chistotela v biologii i medicine Kiev, Naukova dumka.

2. Kaminskyy VO, Lootsik MD, Stoika R (2006) Correlation of the cytotoxic activity of four different alkaloids, from Chelidonium majus (greater celandine), with their DNA intercalating properties and ability to induce breaks in the DNA of NK/ Ly murine lymphoma cells. CEJB 1: 2-15.

3. Jordan MA, Himes RH, Wilson L (1985) Comparison of the effects of vinblastine, vincristine, vindesine, and vinepidine on microtubule dynamics and cell proliferation in vitro. Cancer Res 45: 2741-2747.

4. Taborska E, Bochorakova H, Paulova H, Dostal J (1994) Separation of alkaloids in Chelidonium majus by reversed phase HPLC. Planta Med 60: 380-381.

5. Panzer AL, Joubert AM, Bianchi PC, Hamel E, Seegers JC (2001) The effects of chelidonine on tubulin polymerisation, cell cycle progression and selected signal transmission pathways. Eur J Cell Biol 80: 111-118.

6. Jagiełło-Wójtowicz E, Jusiak L, Szponar J, Kleinrok Z (1989) Preliminary pharmacological evaluation of chelidonine in rodents. Pol $\mathrm{J}$ Pharmacol Pharm 41: $125-131$

7. Kleinrok Z, Szponar J, Matuszek B, Jagiełło-Wójtowicz E (1990) Studies on the participation of the dopaminergic system in the central effects of chelidonine. Pol J Pharmacol Pharm 42: 417-424.

8. Kamins'kyĭ VO, Kryv'iak NV, Lutsyk MD, Stoǐka RS (1999) Effect of alkaloids from celandine on calcium accumulation and oxidative phosphorylation in mitochondria depending on their DNA intercalating properties. Ukr Biokhim Zh 78: 73-78

9. Whiteley CG, Daya JS (1995) Protein Ligand Interactions. Part 5: Isoquinoline Alkaloids as Inhibitors of Acetylcholinesterase from Electrophorus Electricus. Enzyme Inhib 9: 285-294

10. Wang $X$, Zhang $Y$, Yang $Y$, Wu X, Fan $\mathrm{H}$, et al. (2017) Identification of berberine as a direct thrombin inhibitor from traditional Chinese medicine through structural, functional and binding studies. Sci Rep 7: 44040

11. Xia LM, Luo MH (2015) Study progress of berberine for treating cardiovascular disease. Chronic Dis Transl Med 1: 231-235.
12. Anti-platelet Effect of Berberine in Patients After Elective Percutaneous Coronary Intervention (APLABE-PCI). (2017-2018) ClinicalTrials.gov Id: NCT03378934.

13. Huang CG, Chu ZL, Wei SJ, Jiang H, Jiao BH (2002) Effect of berberine on arachidonic acid metabolism in rabbit platelets and endothelial cells. Thromb Res 106: 223-227.

14. Wu JF, Liu TP (1995) Effects of berberine on platelet aggregation and plasma levels of TXB2 and 6-keto-PGF1 alpha in rats with reversible middle cerebral artery occlusion. Yao Xue Xue Bao 30: 98-102.

15. Sun $Y$, Xun K, Wang $Y$, Chen $X$ (2009) A systematic review of the anticancer properties of berberine, a natural product from Chinese herbs. Anticancer Drugs 20: 757-769.

16. Tan W, Li Y, Chen M, Wang Y (2011) Berberine hydrochloride: Anticance activity and nanoparticulate delivery system. Int J Nanomedicine 6: 1773-1777.

17. Eckly-Michel AE, Le Bec A, Lugnier C (1997) Chelerythrine, a protein kinase C inhibitor, interacts with cyclic nucleotide phosphodiesterases. Eur J Pharmacol 324: 85-88.

18. Shimoto H, Matsuda H, Kubo M (1991) Effects of protopine on blood platele aggregation. Effect of protopine on the metabolic system of arachidonic acid in platelets. Chem Pharm Bull 39: 474-477.

19. Chaturvedi MM, Kumar A, Darney BG, Chainy GBN, Agrawal S, et al. (1997) Sanguinarine (pseudochelerythrine) is a potent inhibitor of NF-kappaB activation, IkappaBalpha phosphorylation, and degradation. J Biol Chem 272 30129-30134.

20. Fadeeva MD, Beliaeva TN (1997) Sangunarin and clliptienin cytotoxic isolated from well-known antitumor plants, Intracellular targets of thair action. Tsitologia 39: 181-208.

21. Gadzikowska M, Grynkiewicz G (2001) Commentary on the chromatographic retention of Chelidonium alkaloids. Acta Chromatographica 11: 62-74.

22. Ernst E, Schmidt K (2005) Ukrain-a new cancer cure? A systematic review of randomised clinical trials. BMC Cancer 5: 1-7.

23. Chan K, Zhang HW, Lin ZX (2012) Treatments used in complementary and alternative medicine. Side Effects of Drugs Annual 34: 769-783.

24. Cheng HD, Xiao-Jie G, Pei-Gen X (2015) Phytochemical and biological research of Chelidonieae pharmaceutical resources. Med Plants Chem Bio Omics 171-216.

25. Lee AV, Oesterreich S, Davidson NE (2015) MCF-7 Cells-Changing the Course of Breast Cancer Research and Care for 45 Years. J Natl Cancer Inst 107 djv073.

26. Vazquez J, Long A, Albert S, Brennan M (1973) A human cell line from a pleura effusion derived from a breast carcinoma. J Natl Cancer Inst 51: 1409-1416.

27. Dagur PK, McCoy JP Jr (2015) Collection, Storage, and Preparation of Human Blood Cells. Curr Protoc Cytom 73: 5.1.1-5.1.16.

28. Denholm EM, Wolber FM (1991) A simple method for the purification of human peripheral blood monocytes. A substitute for Sepracell-MN. J Immunol Methods 144: $247-251$

29. Panda SK, Kumar S, Tupperwar NC, Vaidya T, George A, et al. (2012) Chitohexaose activates macrophages by alternate pathway through TLR4 and blocks endotoxemia. PLoS Pathog 8: e1002717.

30. Panda SK, Ravindran B (2013) In vitro Culture of Human PBMCs. Bio-protocol 3: e322.

31. Laemmli UK (1970) Cleavage of structural proteins during the assmebly of the head of bacteriophage T4. Nature 227: 680-685.

32. Chapman JR (2000) Mass Spectrometry of Proteins and Peptides. Humana Press 538

33. Anikina LV, Puxov SA, Dubrovskaya ES, Afanaseva SV, Klochkov SG (2014) Sravnitelnoe opredelenie zhiznesposobnosti kletoks pomoshhyu MTT resazurina Fundamentalnye issledovaniya 12: 1423-1427.

34. Voloshchuk TP, Patskovsky Yu V, Zayika LA (2007) Study of Ukrain composition using HPLC and UV spectroscopy methods. Ukr Bioorg Acta 2: 27-32.

35. Knöpfel SA (1991) Also against gall disease has grown a herb-treatment of diseases of the bile ducts under gallbladder with the natural choledynamic chelononin [A herbal remedy for gall ailments-Treatment of diseases of 
Citation: Deulenko VN, Marunych RY, Chernyshenko VO, Rebriev AV, Lugovskoy EV, et al. (2018) Influence of Chelidonium majus Water Extract onto Cancer Cells and Platelets. Biochem Anal Biochem 7: 370. doi: 10.4172/2161-1009.1000370

the bile ducts and gallbladder with the natural choledynamic chelidonine] Therapeutikon 4: 205-208.

36. Chen J, Zhao H, Wang X, Lee FS, Yang H, et al. (2008) Analysis of major alkaloids in Rhizoma coptidis by capillary electrophoresis-electrospray-time of flight mass spectrometry with different background electrolytes. Electrophoresis 29: $2135-2147$

37. Qing ZX, Cheng P, Liu XB, Liu YS, Zeng JG (2015) Systematic identification of alkaloids in Macleaya microcarpa fruits by liquid chromatography tandem mass spectrometry combined with the isoquinoline alkaloids biosynthetic pathway. $J$ Pharm Biomed Anal 103: 26-34.
38. Qing ZX, Cheng P, Liu XB, Liu YS, Zeng JG, et al. (2014) Structural speculation and identification of alkaloids in Macleaya cordata fruits by highperformance liquid chromatography/quadrupole-time-of-flight massspectrometry combined with a screening procedure. Rapid Commun Mass SP 28: 1033-1044.

39. Zhang Ch, Guo M, Tian Y (2017) Comparative study on alkaloids and their anti-proliferative activities from three Zanthoxylum species. BMC Complement Altern Med 17: 460.

40. Lu JJ, Bao JL, Chen XP, Huang M, Wang Y (2012) Alkaloids Isolated from Natural Herbs as the Anticancer Agents. Evidence-Based Complementary and Alternative Medicine 1-12. 